\title{
SERUM AMYLASE IN PATIENTS OF CHRONIC KIDNEY DISEASE STAGE THREE TO STAGE FIVE
}

\author{
Pal $A^{1^{*}}$, Mandal $L^{2}$
}

\section{Affiliation}

1. Lecturer, Department of Medicine, Karnali Academy of Health Sciences, Nepal.

2. Professor, Department of Medicine, Chitwan Medical College Teaching Hospital, Nepal

\section{ARTICLE INFO}

\section{Article History}

Received : 24 November, 2018

Accepted : 25June, 2018

Published : 31 August, 2018

C Authors retain copyright and grant the journal right of first publication with the work simultaneously licensed under Creative Commons Attribution License CC - BY 4.0 that allows others to share the work with an acknowledgment of the work's authorship and initial publication in this journal.

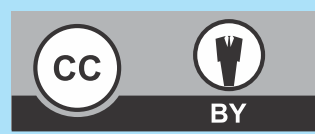

\section{ORA 64}

DOI: http://dx.doi.org/10.3126/bjhs.v3i2.20934

\section{* Corresponding Author}

Dr. Anusmriti Pal

Lecturer

Internal Medicine

Karnali Academy of Health Sciences

ORCID: https://orcid.org/0000.0002-8186-5481

\section{Citation}

Pal A, Mandal L. Serum Amylase in Patients of Chronic Kidney Disease Stage Three to Stage Five. BJHS 2018;3(2)6:403-407.

\section{ABSTRACT}

Chronic Kidney Disease (CKD) is a progressive loss in renal function over period of many months or years. As compared to the past decades, the number of kidney diseases leading to end CKD is increasing in Nepal. The disease is associated with the decreased glomerular filtration rate (GFR). There is decline in nephron function and number generally quantitated as reduction in glomerular filtration rate. As the GFR declines, there is accumulation of metabolic end products excreted by Kidney.

Chronic kidney disease is identified by blood tests, creatinine and urea are two such substances routinely measured. Serum amylase is a pancreatic digestive enzyme that normally acts extracellular to cleave starch into smaller carbohydrate groups and, finally, into monosaccharide's. It is produced by $40-45 \%$ from the pancreas and $(45 \%)$ reabsorbed by tubular cells. Elevations in serum total amylase among patients with CKD is due to impaired renal clearance and seen mostly when the creatinine clearance is below $50 \mathrm{ml} / \mathrm{min}$. Several studies have been reported on this but there are no studies that have been done so far in Nepalese context.

\section{Objectives}

This study is designed to correlate serum amylase with CKD stage three to stage five in patients of chronic renal disease irrespective of hemodialysis and prevalence of risk factors of CKD and different factors that may affect the level of serum amylase in patients presenting to Bir Hospital Nephrology department, Nepal.

\section{Methods}

The study was a cross-sectional, observational, descriptive, hospital based carried out in Nephrology Unit of Bir hospital both inpatient or outpatient irrespective of hemodialysis from March 2014 to March 2015. Patients with increased serum amylase due to acute Pancreatitis, Mumps, Intestinal Obstruction, Peptic Ulcer, Cancer, other than renal cause were excluded. The results were analyzed using SPSS version 11 and Microsoft Excel by correlation coefficient.

\section{Result}

Present study shows that among 126 patients, the prevalence of age group was from 15 years to 78 years with majority being male. The serum amylase levels were significantly higher in Chronic Kidney Disease Stage V with significant p-value. At 80-100 Serum Amylase level had strong correlation of 0.504 for CKD III stage and significant at 10 percent level. The correlation between CKD IV at 80-100 was significant at 10 percent but weak of 0.189 . Whereas, CKD V was highly significant but negative at more than 161 Serum Amylase.

\section{Conclusion}

From the study it was concluded that in Chronic Kidney Disease, Serum amylase was found to be higher as the eGFR decreases.

\section{KEY WORDS}

Chronic Kidney Disease, Serum Amylase, Glomerular Filtration Rate 


\section{INTRODUCTION}

Kidneys are paired intra-abdominal organs with functional unit being nephron. Each nephron is made up of a glomerulus, which comprises four main cell types: endothelial cells; visceral epithelial cells; parietal epithelial cells and mesangial cells. ${ }^{1}$

The ultra filtration rate (glomerular filtration rate; GFR) varies with age and sex but is approximately 120-130 $\mathrm{mL} / \mathrm{min}$ per $1.73 \mathrm{~m}^{2}$ surface area in adults. GFR is defined as the amount of plasma being filtered by the glomeruli per minute. The normal GFR in Indians is approximately 75 to 79 $\mathrm{mL} / \mathrm{min} / 1.73 \mathrm{~m}^{2}$. $^{2}$

In healthy subjects serum urea and creatinine do not rise above the normal range until GFR drops by $50-60 \%$. Renal failure is a condition where kidneys fail to adequately filter waste products from the blood. Two main forms are acute kidney injury, which is often reversible with adequate treatment, and chronic kidney disease, which is often not reversible. $^{2}$

Chronic Kidney Disease (CKD) encompasses a spectrum of different pathophysiology processes associated with abnormal kidney function and a progressive decline in GFR over a period of 3 months. It is estimated by calculating creatinine clearance using different formulas, commonest used is $^{3}$

Cockroft - Gault equation $=(140-$ age $\times w t . / S \mathrm{cr} \times 72)$ (if Female=0.85)

It has been estimated from population survey data that at least $6 \%$ of the adult population in the United States has CKD stages I and II. Nearly $4.5 \%$ of the U.S. population are estimated to have stages III and Stage IV CKD. ${ }^{3}$

Amylase is a digestive enzyme that normally acts extracellular to cleave starch into smaller carbohydrate groups and, finally, into monosaccharides. It is produced by $40-45 \%$ from the pancreas and $55-60 \%$ from the salivary glands. The other locations of amylase include fallopian tubes and cyst fluid, testes, lungs, thyroid, tonsils, breast milk, sweat, tears, and some malignant neoplasm. They contribute little to the serum amylase level. The normal range of Serum amylase is $<80$ Units/liter (U/L). Amylase has a molecular weight of 50,000 Kilo Dalton and mostly (45\%) reabsorbed by tubular cells. ${ }^{4}$

Twenty percent of pancreatic enzymes are excreted by the kidney. Thus patients with end stage renal disease have elevated levels of serum pancreatic enzymes. Humans who have had a nephrectomy or have renal insufficiency have average serum amylase levels $50 \%$ higher than healthy individuals. Therefore, the kidneys can be assumed to play a major role in amylase metabolism. Mostly serum amylase is raised in acute pancreatitis but its relation to renal failure patients is also seen. Serum amylase levels are increased in patients with renal insufficiency due to decreased excretion of the enzyme. The levels are not as high as pancreatitis and there is no relation with degree of uremia. ${ }^{5}$

A study done by Bindu C.M. et al... In Bangalore revealed that "Elevations in serum total amylase among patients with CKD or ESRD is due to impaired renal clearance and seen mostly when the creatinine clearance is below $50 \mathrm{ml} / \mathrm{min}^{5}$

$A$ various studies done in various parts of the world showed varied studies but as such this type of study has not found to be done in our country. The purpose of this study was to correlate serum amylase levels in patients of CKD stage three to stage five regardless of hemodialysis in Bir Hospital, Nephrology department.

\section{METHODOLOGY}

The study was a cross-sectional, observational, descriptive, hospital based carried out among 126 patients above age 15 who got admitted and were visiting Bir Hospital Nephrology Outpatient department (OPD) irrespective of hemodialysis from March 2014 to March 2015, under regular medicine for CKD with clinical, biochemical and sonographic evidence were included in the study after obtaining informed consent. All the patients meeting the criteria were included in the study both from OPD and inpatient. Ethical approval was taken from the Bir Hospital Institutional Review Board (IRB) before starting the research.

Patients with increased serum amylase if occurred due to other than renal cause as acute Pancreatitis, Mumps, Intestinal Obstruction, Peptic Ulcer, Cancer, were excluded. The results were analyzed using SPSS (Statistical Package for Social Science) version 11 and Microsoft Excel using correlation coefficient.

A serum or heparinized plasma free from hemolysis was drawn under aseptic precautions from these subjects in vacuum tube via venipuncture. The blood was then allowed to clot, centrifuged and serum was used to perform biochemical analysis on the same day. Plasma samples that had been anticoagulated with citrate or oxalate and EDTA were avoided as they chelate calcium and chloride which were required as cofactors in reaction resulting in false low levels. $\alpha$-Amylase activity in sample was stable for 7 days at $15-25^{\circ} \mathrm{C}$. Method used in our lab was CNPG (2-chloro-4nitrophenol- $\beta-1-4$ galactopyranosylmaltotrioside) substrate for determination of $\alpha$-amylase activity. The normal range used at $37^{\circ} \mathrm{C}$ is up to $80 \mathrm{U} / \mathrm{l}$.

\section{RESULTS}

126 cases of CKD stage three to five under maintenance hemodialysis or not were included in the present study done in nephrology unit of Bir Hospital, Kathmandu. The age ranged between 15 years to 78 years among which $57.14 \%$ were males and $42.86 \%$ were females with highest percentage belonging to the age group of $36-55$ years (table 1 ) 
Table 1:- Age and Sex distribution of the patients.

\begin{tabular}{|c|c|c|c|c|}
\hline $\begin{array}{c}\text { Age } \\
\text { (years) }\end{array}$ & Male & Female & Female \% & Male \% \\
\hline$>15-25$ & 6 & 8 & 57.14 & 42.86 \\
\hline $26-35$ & 8 & 12 & 60 & 40 \\
\hline $36-45$ & 14 & 15 & 51.72 & 48.28 \\
\hline $46-55$ & 20 & 10 & 33.33 & 66.67 \\
\hline $56-65$ & 17 & 4 & 19.05 & 80.95 \\
\hline $66-75$ & 6 & 4 & 40 & 60 \\
\hline$>76$ & 1 & 1 & 50 & 50 \\
\hline Total & 72 & 54 & 42.86 & $\mathbf{5 7 . 1 4}$ \\
\hline
\end{tabular}

As shown in table 2 serum amylase was in the higher range $>161 \mathrm{IU} / \mathrm{I}$ among CKD stage $\mathrm{V}$ patients with mean value of 231.28 and significant $p$-value. The patients with normal serum amylase in CKD V with mean of 57.6 might be due to patients undergoing hemodialysis. In CKD stage III serum amylase was maximum at range of 80-100 with mean of
87.6; whereas in case of CKD IV serum amylase was maximum at $121-140$ with mean of 129.67 and significant p-value.

The table 3 depicts that correlation between CKD stage III was very weak and had negative correlation with normal range but highly insignificant. At 80-100 Serum Amylase level CKD stage III had strong correlation of 0.504 and was significant at 10 percent level. The correlation between CKD IV and Serum amylase at level 80-100 was significant at 10 percent but weak of 0.189 . It was also found that the CKD V had negative relation at same Serum Amylase of 80-120. Whereas CKD V was highly significant but negative correlation at more than 161 Serum Amylase.

The diagram 1 decipts that CKD of different stages were overlapping in normal range, $80-120$ and $121-140$ serum Amylase except 101-120, 141-160 and greater than 161. This indicates that correlation of eGFR against Serum Amylase was significant at normal range, 80-120 and 121140. It was noteworthy to mention that CKD stage in patients significantly affect in three Serum Amalyse level.

Table 2: Serum Amylase in patients with CKD Stage Three to Stage Five.

\begin{tabular}{|c|c|c|c|c|c|c|c|}
\hline \multirow{3}{*}{ Serum Amylase } & \multirow{2}{*}{\multicolumn{2}{|c|}{$\begin{array}{l}\text { CKD Stage III } \\
\text { eGFR= 59-30 }\end{array}$}} & \multirow{2}{*}{\multicolumn{2}{|c|}{$\begin{array}{l}\text { CKD Stage IV } \\
\text { eGFR= 29-15 }\end{array}$}} & \multirow{2}{*}{\multicolumn{2}{|c|}{$\begin{array}{c}\text { CKD Stage V } \\
\text { eGFR<15 }\end{array}$}} & \multirow{3}{*}{$p$-value } \\
\hline & & & & & & & \\
\hline & Number & Mean & Number & Mean & Number & Mean & \\
\hline Normal $\quad(<80)$ & 17 & 58.41 & 13 & 63.92 & 10 & 57.6 & 0.258 \\
\hline $80-100$ & 18 & 87.61 & 6 & 90.67 & 5 & 88.8 & 0.001 \\
\hline $101-120$ & 3 & 112.67 & 3 & 120 & 1 & 102 & 0.546 \\
\hline $121-140$ & 2 & 127 & 9 & 129.67 & 3 & 132 & 0.032 \\
\hline $141-160$ & 1 & 145 & 4 & 156.25 & 5 & 153.8 & 0.244 \\
\hline$>161$ & 1 & 210 & 7 & 243.71 & 18 & 231.28 & 0.000 \\
\hline
\end{tabular}

Where $r$ is Pearson correlation.

Table 3: Correlation of Serum Amylase in patients with CKD Stage Three to Five.

\begin{tabular}{|c|c|c|c|c|c|c|c|}
\hline \multirow{3}{*}{ Serum Amylase } & \multirow{2}{*}{\multicolumn{2}{|c|}{$\begin{array}{l}\text { CKD Stage III } \\
\text { eGFR= 59-30 }\end{array}$}} & \multirow{2}{*}{\multicolumn{2}{|c|}{$\begin{array}{l}\text { CKD Stage IV } \\
\text { eGFR= 29-15 }\end{array}$}} & \multirow{2}{*}{\multicolumn{2}{|c|}{$\begin{array}{c}\text { CKD Stage V } \\
\text { eGFR<15 }\end{array}$}} & \multirow{3}{*}{ p-value } \\
\hline & & & & & & & \\
\hline & $r$ & $p$-value & $r$ & $p$-value & $r$ & p-value & \\
\hline $\begin{array}{l}\text { Normal range } \\
(<80)\end{array}$ & 0.008 & 0.975 & 0.455 & 0.088 & 0.272 & 0.418 & 0.258 \\
\hline $80-100$ & 0.504 & 0.095 & 0.189 & 0.6 & -0.099 & 0.901 & 0.001 \\
\hline $101-120$ & -0.086 & 0.945 & -1.000 & & 1.000 & & 0.546 \\
\hline $121-140$ & 1.000 & & -0.158 & 0.684 & 0.811 & 0.398 & 0.032 \\
\hline $141-160$ & & & 0.064 & 0.936 & -0.099 & 0.874 & 0.244 \\
\hline$>161$ & & & -0.491 & 0.401 & -0.505 & 0.023 & 0.000 \\
\hline
\end{tabular}

Where $r$ is Pearson correlation. 


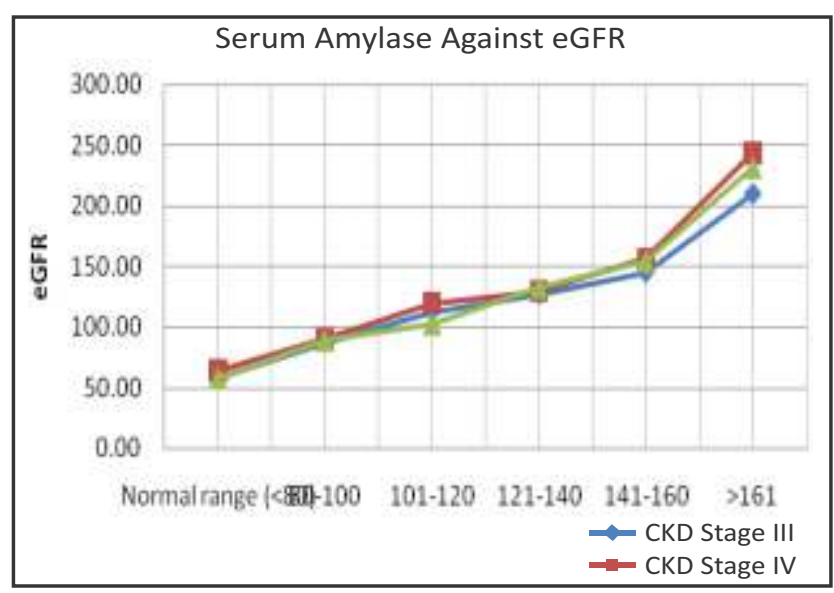

\section{DISCUSSION}

The total number of patients included in this study was 126 which were equally divided into 42 patients in all three groups of CKD Stage three to stage five. Age varied from 15 to 78 years with maximum number of people, falling in the group 46 years to 55 years. There were $57.1 \%$ male and $42.8 \%$ female under CKD stage three to stage five.

M. F. Mahomoodally study tends to show that serum $\alpha$-amylase had a poor correlation with both urea and creatinine in predialysis and post-dialysis samples. ${ }^{6}$ Amita Yadav et al conducted the study to identify whether amylase can be used as an early serum marker of hypertension which showed a statistically significant change in the levels of serum amylase with significant ( $p$-value 0.017). Some also proposed that hypertension may increase capillary pressure and acute elevation in systemic perfusion pressure accelerating hyperfiltration, leading to damage to kidney. ${ }^{7}$

Present study showed that serum amylase was elevated in patients with CKD V more than 161U/I normal being less than $80 \mathrm{U} / \mathrm{I}$. The mean serum amylase level was 231.28 . In CKD III and CKD IV the range was mostly below $80 \mathrm{U} / \mathrm{I}$ that is mostly normal. The highest serum amylase mean value present in CKD III and CKD IV were $210 \mathrm{U} / \mathrm{I}$ and $243.71 \mathrm{U} / \mathrm{I}$ respectively. Study done by JB Keogh et al demonstrates that rise of both salivary and pancreatic amylase in the serum of patients with chronic renal insufficiency compared with controls. This increase was approximately two fold that was less than the corresponding rise in serum creatinine that was three fold. It would appear that in terminal disease associated with renal failure a high amylase/creatinine clearance ratio need not indicate pancreatic disease. ${ }^{8}$

Bindu et al study noted, patients with advanced CKD had higher level of serum amylase (mean 94.4+86.2SD) in comparison to ESRD patients (Mean84.2+22.7SD). It could be due to clearance of amylase during dialysis and malnutrition associated with dialysis. It was found that $60 \%$ of patients had increased serum amylase activity and in 10 patients it was more than twice upper limit of normal. In the same study quoted that Bastani et al study compared 22 peritoneal dialysis patients with 43 hemodialysis patient and 22 non dialyzed chronic renal patients, mean total amylase activity was similar and above the upper limit of normal in all 3 groups it was abnormal in $75 \%$ and above twice upper limit of normal in $24 \%$ of all patients.
Dardamanis et al showed that CRF patients with or without renal replacement treatment have increased values of total amylase as well as of isoamylases, thus confirming the results of previous studies. A significant number of patients had serum amylases more than three times the upper normal limits without exhibiting any clinical sign of acute pancreatitis. ${ }^{9}$

In this study table 4 depicts that correlation between CKD Stage III was very weak and negative correlation with normal range but highly insignificant. The Correlation between CKD IV and Serum amylase level 80-100 U/L was significant at 10 percent but weak of 0.189 . It was found that the CKD V had negative relation at same Serum Amylase of 80-120. CKD V was highly significant but negative at more than 161 Serum Amylase.

As shown in figure 1, it indicates that correlation of eGFR against Serum Amylase was significant at normal range $<80$ $\mathrm{U} / \mathrm{I}, 80-120$ and $121-140$. It was noteworthy to mention that CKD stage in patients significantly affect in three Serum Amalyse level.

\section{CONCLUSION}

Our investigations done among 126 participants indicate that there was a certain amount of retention of amylase in uraemia due to decreased excretion of amylase by the kidneys. Serum total amylase was found to be elevated in chronic kidney disease patients. Serum amylase as a diagnostic tool in recognizing acute pancreatitis leads to false positive results in chronic kidney disease patients. Hence interpretation of elevated amylase in chronic kidney disease patients has to be supported by other laboratory and clinical evidence. As the sample size of our study was small, further studies are required to establish correlation of serum amylase with chronic kidney disease.

\section{RECOMMENDATIONS}

Patients found to have hyperamylasemia should also be considered for having CKD

\section{LIMITATION OF THE STUDY}

Sample Size of this study may not be enough to consider establishing the exact correlation of serum amylase with CKD.

\section{ACKNOWLEDGEMENT}

We would like to acknowledge all respondents for their support, time and participation, without them this study wouldn't have been possible.

\section{CONFLICT OF INTEREST}

We declare no conflict of interest

\section{FINANCIAL DISCLOSURE}

None 


\section{REFERENCES}

1. Praveen K and Michael C. Kumar and Clark's Clinical Medicine. $8^{\text {th }}$ edition. Saunders Elsevier Ltd. 2012:562.

2. Agrawal SK. Kidney Structure and Functions. In: Agarwal AK, Gupta P, Kamath SA, Nadkar MY (Editors). API Textbook of Medicine. Jaypee Brothers Medical Publishers (P) Ltd. 2012; 9 (2):1282.

3. Skorecki K, Bargman JM: Chronic Kidney Disease. In: Longo DL, Kasper DL, Jameson JL, Fauci AS (Eds). Harrison's Principals of Internal Medicine. Newyork: McGraw-Hill Inc, 2012; 18 (2): 2308.

4. Koh D, Ng V, Naing L. Alpha amylase as a salivary biomarker of acute stress of venepuncture from periodic medical examinations. Front Public Health. 2014; 2:121. DOI: 10.3389/FPubh.2014.00121.

5. CM Bindu, P Vidya Shankar, Shetty HV, Gupta Deepti. Serum Amylase in Patients with Chronic Kidney Disease. Int J Cur Res Rev. 2013 Sep; Vol 05 (17):10-15.
6. Mahomoodally M F, Nugessur H. Pre-and Post-Dialysis Correlations of Serum $\alpha$-Amylase, Creatinine and Urea in Chronic Renal Failure Patients. Journal of Medical Research and Development (JMRD). 2014 Apr; Vol. 3, Iss. 2:151-60. ISSN: 2303-9353.

7. Yadav Amita, Singh Ritu. Amylase as an early serum marker for kidney damage in mild hypertension- a pilot study. International Journal of Pharma and Bio Sciences. 2010 Oct-Dec; Vol.1; Issue4:236-38. ISSN 0975-6299

8. Keogh JB, McGeeney KF, Drury M I, Counihan TB. Renal clearance of pancreatic and salivary amylase relative to creatinine in patients with chronic renal insufficiency. Gut.1978; 19:1125-30. PMID: 744498

9. Dardamanis MA, Elisaf MS, Vasakos SA, Tsianos EV. $\alpha$-Amylase and Isoamylase Levels in Renal Transplant Recipients Compared to Uremic Patients. Renal Failure. 1995; 17(6):715-19. DOI: 10.3109/ 08860229509037639 